\title{
THEORIES OF PRIVATE PROPERTY IN MODERN PROPERTY LAW ${ }^{*}$
}

\author{
Sukhninder Panesar ${ }^{* *}$
}

\section{INTRODUCTION}

It is generally accepted that justificatory theories of private property, certainly in the western philosophical tradition, divide roughly into two. This is no better summarized than by Getzler who writes:

\begin{abstract}
" $[t]$ here is a notion of property as presocial, a natural right expressing the rights of persons which are prior to the state and law, this being the view of Hugo Grotius, Samual von Pufendorf, John Locke, Immanuel Kant, and George W.F. Hegel; and there is a notion of property as social, a positive right created instrumentally by community, state, or law to secure other goalsthe theory of Thomas Hobbes, David Hume, Adam Smith, Jeremy Bentham, Emile Durkenheim, and Max Weber."]
\end{abstract}

The philosophical analysis of property is an ever-continuing process since the meaning, function and existence of the institution of private property is not constant but dynamic.

The institution of private property is influenced by a number of factors, not least by the way in which the dominant classes in society expect the institution of private property to serve. In the same way as the dominant classes of society change, so does the institution of private property. ${ }^{2}$ For example, Aristotle,

\footnotetext{
This article is based on a chapter from a forthcoming book written by the author, Concepts in Property Law to be published by Longmans.

"* School of International Studies and Law, Coventry University.

1 J.Getzler, "Theories of Property and Economic Development" Journal of Interdisciplinary History, XXVI: 4 (1996) at p.641. See also, J.Waldron, The Right to Private Property (Oxford, Clarendon Press, 1988); S.Munzer, A Theory of Property (Cambridge University Press, 1990), and more recently, M.J.Radin, Reinterpreting Property (University of Chicago Press, 1993).

${ }^{2}$ For a critical review of the recent and continued philosophical analysis of property see L.Becker, "Too Much Property" Philosophy and Public Affairs, XXI (1992) 196-206.
} 


\section{THE DENNING LAW JOURNAL}

questioning the proper system of property in an ideal constitution, argues for a regime of private property as the best means of attaining net productivity in the utilization of land. ${ }^{3}$ Aristotle argues:
"when everyone has his own separate sphere of interest, there will not be the same ground for quarrels; and the amount of interest will increase, because each man will feel he is applying himself to what is his own."4

This line of argument has more recently been advanced by Demsetz who that writes the "primary function of property rights is that of guiding incentives to achieve a greater internalization of externalities." However, philosophers such as Plato ${ }^{6}$ argued for a regime of communal property as opposed to private, and more recently, Marx commenting on the evils of private property argued for the abolition of private property and the transfer of the ownership of the means of production to the state.

This article explores four dominant justificatory theories of private property with two main objectives in mind. In the first place, the article attempts to show that such justificatory theories and commentary thereupon usually encapsulate three separate questions. The first is the basic question: "What principles decide which individuals have ownership rights over what things?"8 This question is different from the second question which seeks to ask what are the social or public functions of private ownership? The third question, closely related to the second, simply asks: "What individual interests are served by the existence of private property as opposed to some other property regime (such as communism)?"9 Thus, in dealing with justificatory theories for private property, it becomes apparent that theorists either attempt to justify private property by simply looking at the acts of an individual in respect of external resources or they attempt to look at the more broader question of the goals achieved by the existence of private property. The latter does not necessarily entertain questions as to how people become owners of things but merely seeks to provide a plausible explanation for the existence of private property.

\footnotetext{
3 Aristotle, The Politics, (translated by E.Baker, Oxford, Clarendon Press, 1946).

4 Ibid at p.49.

5 H.Demsetz, "Towards a Theory of Property Rights" American Economic Review:

Proceedings and Papers, 57 at p.348 (1967).

6 Plato, The Republic (translated by Desmond Lee, Harmondsworth, Penguin Books, 1974).

7 K.Marx, The Communist Manifesto (Harmondsworth, Penguin Books, 1976).

8 R.Epstein, "Possession as The Root of Title" 13 Georgia Law Review at p.1220 (1979)

9 J.Waldron, supra. n. 1 at p. 1
} 
The second objective of the article is to explore the extent to which these justificatory theories continue to be reflected in modern property law. In other words, are these justificatory theories influential in the judicial law-making process and do they provide a plausible explanation for the existence of private property rights in contemporary property law. In this respect one commentator writes:
"[t]here is a solid consensus among philosophers and legal and political theorists that attempted original acquisitions of private property, when presented in any even remotely plausible form, in fact have little or no interesting force. However compelling their intuitive underpinnings might be, they can justify nothing which helps much in our deliberation about the possible moral defenses of private property in contemporary society.,"10

The article attempts to show that, both original acquisition theories of private property, and those theories of private property which examine the broader question of the goals secured by a regime of private property rights, continue to be reflected in modern property law.

\section{OCCUPATION THEORY}

One of the earliest justifications for private property is contained in what has been called the occupation theory. This theory attempts to answer the relatively simple question of how things become the subject matter of private ownership. We take it for granted that things are ours because we have acquired them from another person who has ownership to pass on to us. Such acquisitions can occur through a voluntary transfer such as a gift or a bequest in a will or; simply by a purchase for value. Thus, the law prescribes methods by which ownership can be acquired from another, for example, a transfer by deed or mere delivery of the thing in question. The law does not, however, tell us how that chain of ownership began, in other words, why was ownership of the thing recognized in the first place?

Early philosophers such as Hugo Grotius ${ }^{11}$ and Pufendorf ${ }^{12}$ argued that the earth's resources were given to mankind in common. Likewise, Blackstone wrote:

\footnotetext{
10 A.J.Simmons, "Original Acquisition Justifications of Private Property" in Property Rights, Paul, Miller and Paul (eds.) (Oxford University Press, 1994) at p.65.

$"$ Hugo Grotius, On the Law of War and Peace, Book 2. Ch.2, 1, 4-5 (Kelsey translation, Oxford, Clarendon Press, 1925)
} 


\begin{abstract}
" $[t]$ he earth... and all things therein, are the general property of mankind, exclusive of other beings, from the immediate gift of the Creator...all was in common among them, and that every one took from the public stock to his own use such things as his immediate necessities required."13
\end{abstract}

In this sense of communal property, private property was born out of individual taking which, Blackstone commented, was for his or her own need. If individuals will claim the material things of the earth, thus effecting demand, such philosophers argued that the resulting scarcity value would naturally require a system of allocation in order to preserve peace and order. Without such a system there would be constant disputes as to what belonged to one person and what to another. The system which gave rise to the institution of private property was first occupation, hence, the occupation theory or justification for private property.

The essence behind the occupation theory is that, given that all material resources are given to mankind in common, such material resources become the private property of individuals through the consent of or agreement with the rest of mankind. The division of property takes place by reference to agreements. Such agreements can be express, that is, a clear acceptance by a group of individuals that material resources, for example land or animals, will be distributed amongst themselves on a mutual understanding. In the absence of such express agreements, an implied agreement could be found on the simple basis of first occupation. The basic principle emerging here is the first occupation gives rise to private property, put into the words of the common law, possession is the root of title. ${ }^{14}$

If the occupation theory holds that an implied agreement will be found amongst individuals that a thing has become the private property of another through occupation, when does first occupation take place? Despite the apparent simplicity of the theory, the question of who has taken first possession is much more difficult when applied to factual situations. The central problem relates to the actual point at which and the amount of labour needed to take first possession. The problem is particularly acute when there are overlapping efforts

\footnotetext{
12 Samuel Pufendorf, Of the Law of Nature and Nations, J. Churchill et.al. (eds.) (1703).

$13 \mathrm{Sir}$ William Blackstone, Commentaries on the Laws of England, Vol. II. para 1 (4 vols., Oxford University Press, 1765-9; rep. University of Chicago Press, 1979).

${ }^{14}$ See for example; Asher v. Whitlock [1865] l Q.B. 1; Perry v. Clissold [1907] A.C. 73; Megarry and Wade, The Law of Real Property (Sweet \& Maxwell, $5^{\text {th }}$ ed., 1984) at pp.105106; Pollock and Wright, Possession in the Common Law (Oxford, Clarendon Press, 1888).
} 
to take first possession. The seminal case which attempts to answer these question is Pierson v. Post, a classic wild animal case from the early $19^{\text {th }}$ century. ${ }^{15}$ The case involved an action of trespass by Post against Pierson on the grounds that Pierson had interfered with Post's property in a wild fox. The facts of the case are relatively simple, Post in possession of certain dogs was hunting on an abandoned beach, having caught sight of a wild fox, he led pursuit for it and had the fox in his gunsight. Before Post had any chance of killing the fox, Pierson intercepted his pursuit and killed the fox and took away the carcass. Pierson's interception took place with the full knowledge that Post was in hot pursuit of the animal. The basis of Post's action was that his pursuit had given him property in the fox that had now been interfered with by Pierson.

The judgments in the case are very interesting and attempt to lay down some general principles as to when first occupation or possession occurs. Justice Tompkins delivered the decision of the majority, who held in favour of Pierson. After citing a long list of authorities both English and American, and consulting the opinion of jurists, the majority held that actual capture and control of the thing in question could give rise to first possession. The hot pursuit of Post was insufficient to give him any property in the fox. Furthermore, it mattered not that Post could have killed the fox had it not have been for Pierson's interception. For the majority, possession meant a clear act whereby the entire world understands that the pursuer has "an unequivocal intention of appropriating the animal to his individual use." Anything short of such an act would be insufficient to give property in the animal. There are sound justifications in this position in that, in the absence of a kill and complete control of the animal, when does the court assign possession? The underlying objective of the majority ruling was to avoid constant disputes and quarrels about when possession takes place.

Justice Livingstone dissented on the grounds that the question of first possession should not be decided by a judge but by a panel of hunters. ${ }^{17}$ In his view the matter would have clearly been decided in favour of Post by such hunters, the majority ruling had the effect of discouraging fox hunting.

Professor Rose as argued there appear to be two principles emanating from the decision in Pierson v. Post as to when first occupation takes place. First, notice to the whole world through a clear act, and secondly, the reward of useful labour. ${ }^{18}$ These two principles require discussion because they seem at first

\footnotetext{
153 Caines. R. 175 (N.Y. Sup. Ct. 1805).

16 Ibid at 178 .

17 Ibid at 180 .

18 See, C. Rose, "Possession as the Origin of Property" 52 The University of Chicago Law Review at p.78(1985)
} 
instance to be rather contradictory. The former principle suggests that first occupation takes place when there is a clear act to the whole world that control has been taken by the possessor. The second principle, however, suggests that first occupation takes place by mixing one's labour, for example, by hunting the thing in question. The second principle on its own leaves a number of difficulties. First, it leaves a number of question unanswered in the decision in Pierson v. Post, and secondly, it fails to explain the difference, if any, between the occupation theory and the rather different labour theory of property which is discussed later on. If the principle is to reward labour then what about the labour employed by Post in his pursuit of the fox? On this second principle, Post should have been entitled to the fox as his property. Despite these initially apparent contradictions, the two principles work hand-in-hand. The central principle is that of notice to the whole world through an unequivocal act to appropriate. The question can be put in the following way; who has exercised a better control $?^{19}$ Labour is important only in so far as making that communication effective. Thus the facts of Pierson v. Post can be explained by stating that, although Post had employed some labour in hunting the fox, his labour had never reached the important stage of communicating notice to the whole world. Pierson's labour had the effect of making that important notice to the whole world.

The rule emanating from the occupation theory of private property is that objects become the private property of individuals when such individuals have taken occupation of them. Occupation is only effective when there has been a clear act of appropriation and which has been communicated to the whole world. Pursuit and acts, which fall short of such an unequivocal act of appropriation, are insufficient because of the problem of assigning possession when there are two or more overlapping efforts to take occupation. The principle behind the occupation theory is thus clear enough, however, it may be questioned whether the theory has any contemporary significance in property law. The primary objection to its continued reliance in contemporary property law is that it is based on facts, which are both historical and primitive. ${ }^{20}$ The conditions operating at the time of writers such as Grotius and Pufendorf simply do not exist in a complex system of resources which we witness today.

Resources are not as commonly held today as they were before, rather, they are

19 This question is employed by the courts in many of the English law cases relating to finding and is also central to the question of whether someone has exercised an appropriate adverse possession of land to thereby extinguish a former legal title.

${ }^{20}$ The theory has been criticized by some as being a mere description of the origin of property, see, for example; R.H.Lowie, "Incorporeal Property in Primitive Society" 37 Yale Law Journal at p.551 (1928). 


\section{THEORIES OF PRIVATE PROPERTY}

more and more parceled into private property. This process having its origins in the $17^{\text {th }}$ century as a result of the spread of the full capitalist market economy in western political systems.

It is submitted that, despite the historical and primitive conditions operating in the occupation theory, the theory remains an important one in present day property law. There are several reasons why the theory is important. In the first place, it cannot be denied that the theory provides the most basic justification for private property. It tells us why private ownership came about in the first place. Many theories on private property attempt to justify the institution of private property, yet they do so not by reference to how such property came about, but rather by looking at the social and economic functions of private ownership. Such theories fail to explain how the chain of ownership began in the first place, instead taking it for granted that the legal system has a concept of private property. In this respect, Epstein writes:

"[i]t could be decided that ownership is necessary to create effective incentives for the development and improvement of property or to reduce or eliminate conflicts between private persons. Yet even if these points are true, such broad justifications for ownership do not solve the more particular question of how given bits of property are matched with given individuals." 21

Secondly, the principle line of thought developed in the occupation theory still continues to be reflected in modern property law. It may well seem that the cases such as the capture of wild animals are more academic than real life legal disputes in property law, however, analogous facts do appear in present day property law. One commentator writes:

"these cases are not silly...people still do find treasure laden vessels, and statesmen do have to consider whether someone's act may support a claim to own the moon, for example, or the mineral nodes at the bottom of the sea." 22

More importantly, however, the principles operating in the occupation theory are still used by the courts in resolving modern day property law disputes. The rule of notice and communication finds itself applicable in the common law cases governing the finding of abandoned and lost objects and also in the law of

\footnotetext{
21 R.Epstein, supra n. 8 at p. 1221

22 C.Rose, supra. n. 18 at p. 75
} 
adverse possession. The common law treats ownership as a relative concept, where objects are lost or abandoned the law allows the finder to assert a fullblooded ownership right against everyone except the original true owner. In such cases of abandoned and lost objects the law has to prescribe conditions under which the finder can assert an ownership right against others. Where objects have been found in a communal or public area, the principle of first occupation has been applied to assign ownership. Thus in one case, Parker v. British Airways Board a passenger who found a gold bracelet in the executive lounge of an airport was allowed to keep the proceeds of sale. ${ }^{23}$ His finding had given him an ownership right binding on the airport which had not made any attempts to control or appropriate lost objects in a public part of the airport. The passenger had, in the context of the occupation theory, made effective notice to the whole world by picking the bracelet and taking control thereof. The airport authority had made no attempt to control lost property by putting up an effective sign to indicate that such lost objects belonged to the airport.

The degree of effort or labour needed to make the communication to the whole world depends on the nature of the resource in question. In Pierson v. Post the degree of effort needed to take control, and thus make communication to the whole world, was to physically capture the wild fox. ${ }^{24}$ However, some resources are incapable of entire physical control, their first occupation is judged be reference to their nature. For example, in The Tubantia the plaintiffs had been doing some salvage work on a wreck which had sunk in 1916 in the North sea. ${ }^{25}$ The plaintiffs, having spent some $£ 40,000$ on the salvage work, managed to make an artificial hole in the side of the wreck and began the process of recovering the contents of the wreck. In 1923 the defendants appeared at the site of the wreck and began their own efforts to recover the wreck and the cargo. The plaintiffs sought a declaration that they were entitled to the wreck and its cargo and that the defendants had interfered with their possession of the wreck. In applying the very same principles enunciated in the occupation theory, the court went on to hold that the plaintiffs were doing with the wreck what an owner or purchaser would have done, their occupation was sufficient to exclude the defendants from interfering with their wreck.

Similarly in the law and policy relating to the adverse possession of land, the rule of notice and communication sufficient to give occupation is clearly a central requirement. The principle of adverse possession recognizes that long uncontested possession of land by a trespasser confers upon such a person an effective title to the land. Leading land law commentators attribute this process

\footnotetext{
${ }^{23}$ [1982] Q.B. 1004.

24 Supra n. 15

25 [1924] All E.R. Rep. 615.
} 
to the self-defining quality of property in land as an empirical fact rather than a question of form based on some abstract theories of ownership. Two such commentators writes:

"[o]n this view property in land is more about fact than about right; it derives ultimately not from words upon parchment but from the elementary primacy of sustained possession., ${ }^{, 26}$

At first instance, disputes relating to the adverse possession of land do not concern questions of first occupation of land. However, the cumulative effect of the Limitation Act $1980^{27}$ and long undisturbed possession by the trespasser do not move the facts too far away from the factual situation of first occupation. In such cases of adverse possession the common law requires the trespasser to have asserted a "complete and exclusive physical control"28 over the land in question.

The principle of first occupation has recently been the subject matter of much discussion in Australia relating to the rights of aboriginal peoples. The High Court of Australia in Mabo v. Queensland (No.2) was forced to recognize the communal native title of the Meriam people to land on Murray Island. ${ }^{29}$ Such communitarian property, a form a private property, was vested in the aboriginal peoples by virtue of tens of thousands years of occupancy. The radical title of the Crown upon settlement was burdened with this native title and as such these peoples were not trespassers. First occupation was therefore clearly important in recognizing such title to the land. In this respect it is important to note that, although legal systems have modified rules of acquisition through statue, such legal systems are nevertheless forced to recognize the rights of individuals and communities who have been in possession of land long before those modified rules of acquisition.

${ }^{26}$ K. Gray and S.F.Gray, "The Idea of Property In Land" Land Law: Themes and Perspectives, Bright and Dewar (eds.) (Oxford University Press, 1998) at p. 19. In referring to "words upon parchment" the authors cite Blackstone who could see "no foundation in nature or in natural law, why a set of words upon parchment should convey the dominion of land..." (Commentaries on the Laws of England, supra n.13 at ii. 2).

27 The Limitation Act 1980 s.15(1) lays down a general rule that "[n]o action shall be brought by any person to recover any land after the expiration of twelve years from the date on which the action accrued to him." The effect of this section is to extinguish the title of the paper owner.

28 Powell v. McFarlane (1977) 38 P \& CR 452, per Slade J. at 470

29 (1992) 66 A.L.J.R. 408 
Finally, the occupation theory is regarded by economists to have a special role to play in the facilitation of trade and the functioning of an effective market. ${ }^{30}$ Property plays an integral part in economic affairs, since by the very definition, economics deals with all things that are both desired and scarce.

Communication and effective occupation has the effect of making it clear who is the owner of a thing, such clear titles facilitate trade by introducing certainty in the market place. Every item of property must be owned by somebody, or by some people in the form of collective property. In the absence of ownership value cannot exist, unequivocal property claims not only allow efficient resource utilization but they also allow property to be traded at it highest value.

\section{LABOUR THEORY: PROPERTY A NATURAL RIGHT}

Legal and political philosophers in the $17^{\text {th }}$ and $18^{\text {th }}$ centuries claimed that the right of individuals to own and dispose of private property was a natural right of the individual. John Locke, for example, in his Two Treatises of Government argued that private property rights existed before the state and independently of laws prescribed by the state. ${ }^{31}$ Property rights were natural rights of individuals and thus governed by principles of natural justice, governmental interference or re-organization of these rights was not permissible without the consent of the individual. ${ }^{32}$ Such natural rights were vigorously defended by political philosophers and indeed formed the basis of revolutionary arguments. In the French and American Revolutions such natural rights were clearly embedded in the resulting declarations. Article II of the French Declaration of 1791 holds that:

"The end of all political associations, is the preservation of the natural and imprescriptable rights of man; and these rights are liberty, property, security, and resistance of oppression., 33

The Fifth Amendment to the Constitution of the United States of America provides:

${ }^{30}$ See R.Posner, Economic Analysis of Law (Boston, Little, Brown, $2^{\text {nd }}$ ed., 1977) at pp.2131

${ }^{31}$ J.Locke, Two Treatises On Government (1690) Book II; see, "Of Property" in

C.B.Macpherson (ed.) Property: Mainstream and Critical Positions (University of Toronto Press, 1978) at p. 17.

${ }^{32}$ For a detailed account of Locke's discourse on property see, J.Tully, A Discourse on Property: John Locke and Adversaries (Cambridge University Press, 1980), and; J.P.Day, "Locke on Property" 16 Philosophical Quarterly (1966) at pp.207-221

${ }^{33}$ Quoted in A.Ryan, Property (Open University Press, 1987) at p.61. 


\section{THEORIES OF PRIVATE PROPERTY}

"No person...shall be deprived of life, liberty, or property, without due process of law; nor shall private property be taken for public use without just compensation.",34

The idea of natural rights is far from clear. With a history of some two and half thousand years, what constitutes natural law and natural rights has provoked and continues to provoke different answers. ${ }^{35}$ The traditional line of argument behind natural law is that there are certain rights which are derived from the law of God, nature or reason. There are certain moral principles which depend on the nature of the universe and which are discovered by reason. It is these principles, such as the right to life, liberty and pursuit of happiness, which form natural rights and are protected by natural law. Such laws are not prescribed by state, they exist before the state and are higher laws which all states and legal systems therein are subject to. Although it is commonly accepted that natural law is derived from nature itself and discovered by reason, there have been different lines of thought as to what is exactly meant by nature and reason. If such laws are discovered by reason, then whose reasoning prevails? Such a question is by its very nature subjective, and thus, susceptible to many different answers. D'Entrèves has pointed out "many of the ambiguities of the concept of natural law must be ascribed to the ambiguity of the concept of nature that underlies this. ${ }^{~} 36$ Despite this, Freeman points out that:

"[v]iews as to the content of these principles have sometimes diverged but the essence of natural law may be said to lie in the constant assertion that there objective moral principles which depend upon the nature of the universe and which can be discovered by reason. These principles constitute natural law. ${ }^{\text {,37 }}$

John Locke argued that the right to private property was one of the natural rights of an individual and consequently protected by natural law. The right was natural, not in the sense that every individual was born with the right to property, rather, the right was acquired through conduct which is natural to

\footnotetext{
34 S.E.Finer, Five Constitutions (Oxford, Clarendon Press, 1979) at p.106.

${ }^{35}$ For a good overview of natural law thinking see M.D.A. Freeman, Lloyd's Introduction to Jurisprudence (London, Stevens, $6^{\text {th }}$ ed., 1994) at p.79 and R. Tuck, Natural Rights Theories (Cambridge University Press, 1979). The most forceful recent statement of natural law is provided by J.Finnis, Natural Law and Natural Rights (Oxford, Clarendon Press, 1980).

${ }^{36}$ Natural Law (London, Hutchinson, rev.ed., 1970) at pl6.

37 M.D.A.Freeman, supra n. 35 at p. 80.
} 


\section{THE DENNING LAW JOURNAL}

man. Private property rights were acquired by natural, moral and rationale conduct which individuals left to their own devices would perform. As such private property was acquired separately and did not arise through the prescriptive law of the state. Locke maintained that it was God and not sovereign that gave property, and thus, private property existed even before sovereign and state. The role of government was to protect to the right of property along with other rights such as the right to life and liberty. Indeed, such argument was used to refute the claims of Charles I in England that sovereign could interfere with the property of individuals without their consent for the public good.

Like Pufendorf ${ }^{38}$ and Grotius, ${ }^{39}$ Locke begins his justification for private property on the same premise that resources are given to mankind in common, the original state of property is that it is held in common. The basis of his thesis thereafter can be summarized in three main points. In the first place, every man has a right to his own person, we may describe this as self-ownership. ${ }^{40}$ Secondly, every man has a right to own his own labour. Finally, every man has a right to own that which he has mixed the labour of his own person with. Mixing one's labour with the common resources which God has given to mankind extracts that which was held in common into private ownership. This process taking place as a result of the natural conduct of man and not through the process of law prescribed by the state.

Locke begins his justification for private property on the same premise as the occupation theory, that is, the earth and all the resources within it are given to mankind in general. Locke writes:

"God, who hath given the World to Men in common, hath also given them reason to make use of it to the best advantage of Life, and convenience. The Earth, and all that is therein...belong to Mankind in common, as they are produced by the spontaneous hand of Nature; and no body has originally a private Dominion, exclusive of the rest of Mankind, in any of them, as they are thus in their nature state...,41

\footnotetext{
${ }^{38}$ Supra n. 12.

39 Supra n.11.

40 The use of the word "man" is deliberately used here reflecting the ideological thinking of the time and the role of man as being far more important in acquiring property rights.

${ }^{41}$ Two Treatises of Government (1690) "Second Treatise of Government" Ch.5. para.26, reprinted in C.B.Macpherson, supra n. 31 at p.17.
} 


\section{THEORIES OF PRIVATE PROPERTY}

God gives the earth and the resources within it to man in common, no individual has an exclusive dominion. In this respect Locke attempts to show that the state and sovereign have no exclusive rights to resources which allows them to interfere with and control those resources per se.

In this state of common property, Locke attempts to show that private property is born out of two natural principles. The first is that, every individual has by nature property in his own person, sometimes referred to as selfownership. Locke writes "every man has Property in his own Person. This no Body has any Right but to himself. "A2 The Lockean idea of ownership in one's self has been the subject matter of much debate. ${ }^{43}$ Waldron writes that "[a] more promising suggestion is that self ownership and the ownership of actions amount for Locke to a right to personal liberty. ${ }^{, 44}$ To have ownership in one's person is to have ownership in his actions, such actions belong to him since he has a natural right to perform them without any obstruction. The second principle, and one which flows from the first is that, one of the actions which an individual will perform is to labour on resources which have been given in common. Labour of an individual belongs to the individual alone, consequently, Locke argues that when such labour is mixed with common resources such resources are taken from the common and put into the sphere of private property. Labouring gives the labourer an exclusive private property right to the resource or thing in question. The object in which labour has been expended contains something which the labourer owns and as such any taking of the object or other interference amounts to a violation of the individuals natural right to the object.

Labour, is thus, the central features of Locke's justification for private property, however, it does not explain the extent of private property. It is fair to say that labour on resources will give individuals private control of those resources, yet there are some unanswered questions. How much private property can an individual acquire under the Lockean theory? How much labour need one expend before he or she becomes entitled to the thing and does labour have to reflect the value added to the resource in question? Locke addresses the first question raised here in his theory, the latter is not discussed and as such has been the more critical aspect of his theory. Although labour gives birth to a private property right, Locke does impose restrictions on the amount of such

\footnotetext{
42 Ibid para. 27 at 18.

43 See, for example, J.Tully, supra n.32 at p105 who argues that the term "person" is a technical term quite distinct from "body." Tully argues that such use of the word person more accurately describes personal identity, thus, an individual has ownership in his personal identity. For a critical account of ownership in one's self, see; J.P.Day, supra n. 32.

${ }^{44}$ Waldron, supra n. 1 at p. 181.
} 
property. In his writings one identifies two limitations on the labour principle, namely; the "spoilation proviso" and the "sufficiency limitation."

First, although labour will give private property, if the labourer does not use resources, then despite his labour, those resources do not belong to him but become common again. He writes:

"God has given us all things richly... But how far has he given it us? To enjoy. As much as any one can make use of to any advantage in life before it spoils; so much may be by his labour fix a Property in. Whatever is beyond this is more than his share, and belongs to others. ${ }^{* 45}$

This has often been referred to as the "spoilation proviso," ${ }^{, 46}$ and has been described by Waldron as:

"a generous one, because Locke's concept of use is very broad.

It is to any advantage of life and therefore is not confined to consumption or production for consumption, but also includes, for example, aesthetic uses and the use of objects as a commodity in exchange. ${ }^{.47}$

Although Locke provides for this spoilation limitation, he does not see that there would by any problems of excessive concentration of private property into certain hands at the expense of others. This is simply because in his thesis he regards right and convenience to go hand in hand. Thus, any labour which is mixed with more than that is needed for one's convenience simply goes back into the common. Locke noted that:

"there could be no reason for quarreling about Title, nor about the largeness of Possession it gave. Right and conveniency went together; for as a Man had a right to all he could employ his Labour upon, so he had no temptation to labour for more than he could make use of. "48

\footnotetext{
45 J.Locke, "Second Treatise on Government" para. 31, in C.B.Macpherson, supra n. 31 at p19.

${ }^{46}$ See, J.H.Bogart, "Lockean Provisos and State of Nature Theories"95 Ethics (1985).

47 Waldron, supra n. 1 at p. 207.

48 J.Locke, "Second Treatise on Government" para.51, in C.B.Macpherson supra n. 31 at p27.
} 
This proviso works well enough in a social and economic climate where right and need go together, however, as Dunn has pointed out, the role of exchange and money did put a rather different emphasis on the matter. ${ }^{49}$ Dunn writes that the introduction of money meant that:
"right and conveniency no longer went together. The entire social and economic order of the seventeenth-century England rested upon a human institution about whose moral status Locke felt deeply ambivalent." 50

The second limitation on property in Locke's theory is that, an individual who does labour, must leave behind enough resources of the same quality for others to appropriate. This is necessary because the function of property in Locke's theory is the satisfaction of need. Without such property individuals cannot exist, human needs dictate that there should be private property. This limitation has been described as the "sufficiency limitation," appropriation illegitimate when there is insufficient left for the needs of others. Locke writes:
"[f]or this Labour being the unquestionable Property of the Labourer, no Man but he can have a right to what that is one joyned to, at least where there is enough and as good left in common for others." 52

At first instance, this limitation of the right to appropriate seems rather paradoxical, for example, Thomson writes:

"if the first labour-mixer must literally leave as much and as
good for others who come along later, then no one can come to

49 J.Dunn, The Political Thought of John Locke (Cambridge University Press, 1969) at p.40.

so Ibid. Writers like Dunn have sought to argue that the introduction of money was somewhat at odds with Locke's theory. Waldron, supra n. 1 at p209, however, argues that in respect of the Locke's spoilation proviso, it is not rendered ineffective by new conditions in economy. This is simply because the amount of appropriation is determined by labour and not the proviso. Providing there is labour and some element of use and consumption, use having a very wide meaning, the labourer is entitled to everything which does not perish.

${ }^{51}$ C. B.Macpherson, The Political Theory of Possessive Individualism: Hobbes to Locke (Oxford, Clarendon Press, 1962) at p.211.

52 J.Locke, "Second Treatise on Government" para.27, in C.B.Macpherson supra n.31 at p18. 


\section{THE DENNING LAW JOURNAL}

own anything, for there are finitely many things in the world so that everyone taking leaves less for others." 53

The Lockean justification for private property works well under conditions of plenty, since under conditions of plenty and lack of scarcity this sufficiency limitation will never be violated. The social and economic conditions operating at the time of Locke's writing may well have made it impossible for appropriation to become illegitimate by virtue of the sufficiency limitation. The reason for this is that Locke associates private property rights with convenience, such convenience being the satisfaction of human needs and subsistence.

Anything beyond this would be improper, for example, the idea of property and convenience going together is illustrated when he states that there would be enough land in the world for twice its population:

\section{"had not the Invention of Money, and the tacit Agreement of Men to put a value on it, introduced (by Consent) larger Possessions, and a Right to them....54}

The sufficiency limitation works well under conditions of plenty, but under conditions of scarcity all appropriation becomes illegitimate for the reason stated above. Does the Lockean justification for private property, therefore, become redundant? This is a question which has provoked different responses. One response is that in an age of scarcity, unilateral appropriation becomes no longer possible and property must be distributed in different way, for example through consent. Perhaps the most effective interpretation of the sufficiency limitation is that provided by Waldron. ${ }^{55}$ Waldron explains that the sufficiency limitation is not really a limitation in its own right but, rather, an effect of the spoilation proviso discussed above. He gives the example of an individual living under conditions of modest scarcity, such individual needs to appropriate resources for his needs but he realizes that his appropriation will leave less for others who have a similar need to appropriate. If the sufficiency limitation is taken to its logical conclusion, does he sit back and starve? Indeed, to appropriate under such conditions he would be violating natural law. In the context of this example, Waldron explains that such a conclusion would be

${ }_{53}$ J.J.Thomson, The Realm of Rights (London, Harvard University Press, 1990) at p.330. Thomson is not alone in making this point, J.H.Bogart writes: "[e]very acquisition worsens the lot of others- and worsens their lot in relevant ways" supra n. 46 at p.834.

54 J.Locke, "Second Treatise on Government" para.36. in C.B.Macpherson supra n.31 at p. 21.

S5 Supra n.1 at pp.211-213 


\section{THEORIES OF PRIVATE PROPERTY}

absurd and inconsistent with the substance of Locke's theory of property. It would in effect mean that because every one else in the world is in a similar position everyone has to starve.

Waldron writes:

"all God's human creatures would perish notwithstanding the fact that He had provided resources for the sustenance of at least some of them. Such a result, dictated by the alleged proviso in conditions of scarcity, is absurd... It follows, surely, that he who appropriated the food and shelter he really needs is entitled, even bound to use them-irrespective of the needs of others. ${ }^{256}$

The only limitation being that if he appropriates more than his needs then others have a right to be sustained out of his surplus.

Schmidtz provides a somewhat different response to the sufficiency limitation. ${ }^{57}$ Schmitdz explains that appropriation is not what he calls a "zero sum game. ${ }^{.58}$ It is not plausible for philosophers on original acquisition, and for that matter subsequent readers of the theories provided by such philosophers, to maintain that all appropriation takes place by the first person to arrive. First appropriation is just the beginnings of creating the resource in question, the real benefits to be enjoyed by later owners. Schmitdz neatly explains the point when he writes:

"[o]riginal appropriation diminishes the stock of what can be originally appropriated, but that is not the same thing as diminishing the stock of what can be owned. On the contrary, in taking control of resources and thereby reducing the stock of what can be appropriated, people typically generate massive increases in the stock of what can be owned. The lesson is that appropriation is not a zero-sum game. It is a positive sum game. As Locke himself stressed, it creates the possibility of mutual benefit on a massive scale., ${ }^{, 59}$

The question was raised above regarding the extent of labour needed before I can regard the thing in question as mine. This is different from the question

Ibid at p. 214 .

7 D. Schmitdz, "The Institution of Property" in Property Rights, Frankel, Miller and Paul (eds.) (Cambridge University Press, 1994) at p.42.

38 Ibid at p.45

59 Ibid at p.46. 


\section{THE DENNING LAW JOURNAL}

discussed so far, that is, how much private property I can acquire under Locke's theory? Whilst the amount of private property which can be acquired or appropriated is governed by the spoilation proviso and the sufficiency limitation, a question which is not directly tackled by Locke is the relationship of labour to the value added to the thing in question. It is this aspect of his theory which has been the subject matter of criticism. Nozick makes the point that, even if labour can be owned and such labour is mixed with resources, does it automatically mean that the resources becomes the private property of the labourer $?^{60}$ For example, if I make the very first effort to extract the oil from the bottom of the seabed, am I entitled to the world's supply of oil? Nozick's primary concern relates to the fact that where labour is expended by the labourer, why should the labourer be entitled to an exclusive right over the resource in question? His right should only extend in so far as to the added value to the resource in question. The potential problem with this line of attack by Nozick is that how does one practically discriminate between lesser and greater interests in resources in a simple state of nature. Waldron makes the point that only in a positive legal system can different estates and interests in the same object be recognized, distinguished and upheld in law. ${ }^{61}$ The plausible explanation here is that in a state of nature full and exclusive entitlements are only provisional and in any event:

"could not operate as moral constraints on the activity of a subsequently instituted civil society which was determined to strike retrospectively and in rectification of the crudeness of the natural entitlements on a fair balance between the legitimate claims of the appropriator and those of the rest of mankind. ${ }^{\prime 62}$

A second criticism directed at Locke's theory is why should the mixing of labour with a resource give any entitlement at all? The much quoted question which Nozick asks is:

"[w]hy isn't mixing what I own with what I don't own a way of losing what I own rather than a way of gaining what I don't have. If I own a can of tomato juice and spill it into the sea so that its molecules... mingle evenly throughout the sea, do I

60 R.Nozick, Anarchy, State and Utopia (Oxford, Blackwell, 1974) at p.175.

61 Supran. 1 at p. 191 .

62 Ibid. 


\section{THEORIES OF PRIVATE PROPERTY}

thereby come to own the sea, or have I foolishly dissipated my tomato juice? ${ }^{, 63}$

This question posed by Nozick is often taken to illustrate the shortcomings of the labour principle in Locke's theory, however, as one commentator explains such criticism is inappropriate. ${ }^{64}$ Duxbury gives two reasons; in the first place, Locke only recognizes those activities which improve the resource as constitutive of labour. Secondly, a person who does labour and makes no improvement to the resource in question or even diminishes its value, is simply acting irrationally or out of ignorance.

How far is the natural right justification for private property relevant in modern property law? Critics of the natural law theory of private property reject it has having any significance in modern property law. In the first place, there appears to be the theological dimensions to the theory and the resulting question as to how, and the extent to which, the Church continues to influence the legal policy making process. Legal philosophers argue that private property must be justified by some greater social and economic objective rather than by reference to historical entitlement. Like the occupation theory the view is that such a theory only explains the principle of original acquisition. The matter is perhaps no better summed up than by Simmons who writes:

"[t]here is a solid consensus among philosophers and legal and political theorists that attempted original acquisition justifications of private property, when presented in any even remotely plausible form, in fact have little or no interesting justificatory force. However compelling their intuitive underpinnings might be, they can justify nothing which helps much in our deliberation about the possible moral defenses of private property in contemporary society. "65

Simmons, however, challenges this consensus by examining the idea of justification of private property. His main aim is to show that when philosophers talk of justifying private property, the concept itself is very vague. Justifications of private property can be one of two types, namely, "optimality justifications" or "permissibility justifications. ${ }^{266}$ The former justification looks

${ }^{63}$ Supra n.60 at pp. 174-75.

${ }^{64}$ N.Duxbury, Theorising Private Property Rights (University of Manchester Working Paper No. 20 1996) at p.11.

${ }^{65}$ A.J.Simmons, supra n. 10 at p.65

66 Ibid at p. 66. 
to the wider social, moral and economic goals of having one type of property over another. Thus, an optimal justification of private property would sound something like this: it is better to have private ownership because it provides for the greater human happiness in society or it is the best means of efficient utilization of resources. On the other hand, permissibility justifications simply look to what was morally permissible or morally legitimate. The everyday actions of an individual are not always done with the individual seeking to do what was optimal in the sense of the best alternative. Individuals do not necessarily do what was the best thing they could have done in the circumstances, rather, they do things because they think they are morally permissible or otherwise legitimate without any wider objective goal in mind. In this context, Simmons writes:
"the primary force of Locke's original justification of private property is to display private property rights as morally possible and permissible... The permissibility arguments constitute an attempted justification of private property, they show that private property claims can be legitimate (i.e. morally acceptable), probably were once mostly legitimate and may still be legitimate in certain contexts." 67

Finally, the principles emerging from the labour theory continue to be reflected in intellectual property rights and in the law and policy concerning unfair competition. ${ }^{68}$ Individuals who create, manufacture or invent things through their labour and intelligence seek to make these things theirs through their acts of labour. It has been said that the law of intellectual property, "is a branch of law which protects some of the finest manifestations of human achievement. ${ }^{, 69}$

\section{UTILITARIAN THEORY OF PRIVATE PROPERTY: PROPERTY A POSITIVE RIGHT}

The utilitarian theory of property regards property as a positive right created instrumentally by law to achieve wider social and economic objectives.

Property is said to be a positive right as opposed to a natural right. The essence

\footnotetext{
67 Ibid at p.73

68 See, for example, R.G.Hammond, Personal Property Law (Oxford University Press, 1992) at p.51

${ }_{69}$ W.R.Cornish, Intellectual Property: Patents, Copyright, Trade Marks, and Allied Rights (Sweet \& Maxwell, $2^{\text {nd }}$ ed., 1989) at p.3.
} 
of a positive right is that it is prescribed by state, the right is both given and protected by state. The most influential utilitarian justification for private property is that of Jeremy Bentham contained in his Principles of the Civil Code. ${ }^{70}$ The principal thrust of Bentham's argument is that the total or average happiness of society cannot be maximized unless there exists rights to appropriate, use and transfer objects of value or interest. In order to understand the utilitarian justification for private property it is necessary to understand exactly what is meant by the concepts of utilitarianism and positive law.

Jeremy Bentham rejected that there could be any notion of natural law and natural rights. In his words, "[n]atural rights is simple nonsense: natural and imprescriptable rights, rhetorical nonsense, -nonsense upon stilts." Bl Bentham argued that all laws flowed form the state alone, states prescribed laws and such laws were positive laws. The principle upon which a law would be prescribed was the principle of utility. The concept of utility and utilitarianism is explained by one commentator in the following manner:
"[t]he classical utilitarian theories (of Bentham, J.S.Mill...) took the fundamental basis of morality to be a requirement that happiness should be maximized: the basic principle of utility required us to weigh up the consequences, in terms of happiness and unhappiness of various alternative actions, and choose that action which would, on balance, have the best consequences, in the sense of producing the largest net balance of happiness.",72

The principle of utility alone governs what we should or should not do, in other words, the principle is used by state and sovereign and its law-making authorities to command rules. Law and rights are not dependent on moral judgments and our actions cannot be simply justified on past facts.

In rejecting property as a natural or moral right of an individual, Bentham claimed that private property and law are born and die together. Without laws

\footnotetext{
${ }^{70}$ (1830), see his analysis of property in C.B.Macpherson, supra n.31 at pp.41-59. The best edition is that contained in Jeremy Bentham, The Theory of Legislation, C.K.Ogden (ed.) (London, Routledge, 1931)

$7_{1}$ J.Bentham, "Anarchical Fallacies" in Nonsense Upon Stilts: Bentham, Burke, and Marx, on the Rights of Man, J.Waldron (ed), (London, Methuen, 1987) at p.53.

72 N.E. Simmonds, Central Issues in Jurisprudence: Justice, Law and Rights (Sweet \& Maxwell, 1986), at p.15. There is no scope in this article for a complete analysis of utilitarianism, however, for further analysis, see ; J.J.C.Smart and B.Williams, Utilitarianism: For and Against (Cambridge University Press, 1973); D.Lyons, Forms and Limits of Utilitarianism (Oxford, Clarendon Press, 1965); Sen and Williams (eds.) Utilitarianism and Beyond (Cambridge University Press, 1982).
} 


\section{THE DENNING LAW JOURNAL}

there is no private property, thus, even where a person is to labour on a resource, his only entitlement to the resource is the guarantee that the law will assure the enjoyment of his labour. In this sense laws perform the function of security, without which there would be misery and a denial of the right to subsist. The positivist nature of the right to private property is clear when Bentham writes:

"[t]he idea of property consists in an established expectation; in the persuasion of being able to draw such or such an advantage from the thing possessed, according to the nature of the case. Now this expectation, this persuasion, can only be the work of the law. I cannot count upon the enjoyment of that which I regard as mine, except through the promise of the law which guarantees it to me."73

Bentham argues that that the greatest or total happiness in society in respect of resources will only come about if such resources are in the hands of private individuals, how does he apply the utility principle to private property? The assumption is that acquisition of wealth is good, but good in what manner? In respect of the utility principle Duxbury writes:

"the principle is inherently vague in that it is not entirely clear how it is supposed to be applied or how utility might be measured or - assuming satisfactory criteria for measurement are devised - how the utilitarian is expected to balance one person's gain in utility against a loss in that of another."74

Bentham does not provide a precise way in which human happiness can be measured, instead, in his work Bentham identifies what he calls "evils" resulting from violations of private property.

The first evil which Bentham comments upon in Principles of the Civil Code is the evil of non-possession. The acquisition of a resource is a good thing, nonpossession on the other hand an evil since the resource is simply being wasted. Secondly, there is the pain of losing since, where I do have private property and possession of things, such property performs different functions and represents to the individual different values. Property may have an intrinsic value but it also has a value of affection, for example, as an inheritance, as the reward of labour, of the provision for dependents. Thirdly, there is the fear of losing what

73 J.Bentham, Principles of the Civil Code (1830) in C.B.Macpherson supra n. 31 at p.52.

74 N.Duxbury, supra n.64 at p.4. 


\section{THEORIES OF PRIVATE PROPERTY}

one already has. Whilst individuals have property, future acquisitions are necessary to supplement the ones which an individual already possesses. If the law does not guarantee private property then there is a fear of losing what we already have, this is a bad thing, since resources are not utilized properly. Instead they are hidden or preserved and the enjoyment of them becomes "sombre, furtive, and solitary." 75 Finally, there is what Bentham describes as the deadening of industry which arises form the insecurity of labour and the resulting fruits of labour. Bentham argues that it is the law alone can give security in respect of these four evils.

One of the shortcomings of Bentham's utilitarian justification for private property is that it does not address the question of how people become to own resources and how initial distribution arises in the first place. Bentham's philosophy of property and law was written in a period witnessing the end of the medieval period and the beginnings of a capitalist economy. Certainly his ideas were influenced by the industrial revolution and the rise of nation states anxious to assert total independence in this age of economic expansion. It may be that Bentham had no need to worry about how initial acquisitions of property occurred, instead justifying private property in this age of economic expansion. Land had become more and more parceled into private ownership and rights in land more absolute. ${ }^{76}$ In so far as the question of initial distribution of wealth and resources, it is commonly said that the utilitarian is not concerned with this question since his primary aim is the maximization of welfare. Presumably this means that that those who have the largest amount of property will have the greatest opportunity to maximize wealth. What about those who have nothing or very little? Is the utilitarian concerned about the distribution of welfare or is the divide between poor and rich not a concern for a utilitarian?

It is submitted that the distribution of welfare is a central concern for the utilitarian and thus an integral part of any utilitarian justification for private property. Distribution of welfare can take place on the theory of diminishing marginal utility which itself needs to be balanced with the objectives of maximization of welfare. Simmonds ${ }^{77}$ explains the theory of marginal utility with the following example; an extra $£ 1$ given to a millionaire will make an negligible contribution to his welfare, whereas $£ 1$ given to a very poor person might make a significant contribution to his welfare, enabling him, perhaps, to buy a meal which he would not have been able to afford. The $£ 1$ in the hands of

\footnotetext{
75 J.Bentham, Principles of the Civil Code (1830) in C.B.Macpherson supra n. 31 at p.54.

76 See, for example, C.B.Macpherson, "Capitalism and the Changing Nature of Property" in E.Kamenka and R.S.Neale (eds.) Feudalism, Capitalism and Beyond (London, Edwards Arnord, 1975) at p. 105.

77 Supra n. 72 at p. 32
} 


\section{THE DENNING LAW JOURNAL}

the poor man has the effect of maximizing welfare on a much greater scale than in the hands of a rich man. However, marginal utility needs to be balanced with the fact that high productivity requires resources to be placed in the hands of individuals who have strong incentives to work hard. Strict equality of resources will inevitable bring about a reduction in the productivity and welfare in the long run. In this respect, Simmonds explains that a utilitarian can offer a plausible response to distributive issues, he identifies two main arguments which purport to show the distributive nature of utilitarian arguments. He writes:

"[f]irst the utilitarian can claim that his theory explains the way in which we do in fact trade off equality against productive and economic efficiency. This trade off is neither arbitrary nor hypothetical: it reflects the fact that the underlying concern is the maximization of welfare, that being a goal to which both redistribution and higher productivity can contribute. Secondly, the utilitarian can argue that he alone has offered a plausible explanation of why redistribution matters. When we take money from the rich and give to the poor, he may argue, we do this because we believe it will do more good relieving poverty than being spent on trivial comforts.

Seen in this way, like the Lockean natural right justification for private property, there are limitations on the extent of private property under a utilitarian justification. Under Locke's theory we identified the spoilation and sufficiency limitations, the utilitarian principle of maximization of welfare does accommodate the need for distribution to others.

\section{ECONOMIC JUSTIFICATIONS FOR PRIVATE PROPERTY}

In more recent times philosophers have advanced economic justifications for private property. This has been part and parcel of a process whereby laws have been analyzed from a purely economic perspective which, in substance, represents a scientific alternative to utilitarianism as discussed above. ${ }^{79}$ Property underlies each and every aspect of economics, since by its very definition,

78 Ibid at p.33.

79 The economic analysis of law has generated a vast literature, see R.Posner, supra n. 30 A.M.Polinsky, An Introduction to Law and Economics (Boston, Little, Brown, 1989); and in the context of property rights, see, B.Ackerman, The Economic Foundations of Property Law (Boston, Little, Brown, 1975). 


\section{THEORIES OF PRIVATE PROPERTY}

economics deals with all things of worth. Posner argues that the legal protection of property rights performs a very important economic function, that is, to create incentives to use resources much more efficiently. ${ }^{80}$ Posner identifies three criteria for an efficient system of property rights. First, "universality" that is all resources should be owned by someone or capable of being owned except those resources which are so abundant that consumption does not reduce the resource for others. Secondly, "exclusivity," that is, to give owners the incentive to incur the cost required to make efficient use of resources which they own. Finally, "transferability," property rights should be able to be freely transferred since this is the only way that a resource can be shifted from a less productive use to a more productive one. In substance, this economic justification for private property argues that there are costs or disutilities when there is no ownership of resources. If these costs are much greater than the costs involved in having a private property regime, then a system of private property rights is justified by considerations of economic efficiency. The essence of the economic justification for private property is the minimizing of cost and the resulting efficiency in distribution of resources. ${ }^{81}$

Like Posner, Demsetz argues that the general welfare will be better served if material resources are owned and controlled by private individuals. ${ }^{82}$ A system of private ownership is much better than any other, such a communal, because individuals will not feel the full impact of the benefits of his use and also the costs of his use. According to Demsetz, the "primary function of property rights is that of guiding incentives to achieve a greater internalization of externalities. ${ }^{283}$ He gives the example of a communal ownership of land by a

${ }^{80}$ Ibid at pp. 10-13.

81 The economic idea of efficiency is construed in one of two ways: Pareto efficiency and Kaldor-Hicks efficiency. A situation is said to be Pareto optimal if it is impossible to change it without making at least one person believe he is worse of than before the change. Thus, under this principle an allocation of resources will be Pareto optimal, if any other different system of allocation makes one person better off but only to the cost of another. A situation may be Pareto superior if a change produces a gain in one person but not at the expense of anyone else, in other words, one person is better of and no one else is affected in terms of loss. The difficulty with the Pareto standard applies when there are no losers, however, most rules and social policies produce both winners and losers. The Kaldor-Hicks test gets round this problem by allowing a situation to be optimal or efficient if someone is made better off by a change but losers are fully compensated for their loss. Thus, an allocation of resources will be efficient where those who lose as result of the allocation are fully compensated. See J.L.Coleman, "The Economic Analysis of Law" in J.R.Penncock and J.W.Chapman (eds.) Nomos XXIV: Ethics, Economics, and the Law (New York University Press, 1982) at pp.83103.

82 H.Demsetz, supra n.5.

83 Ibid at p.348 


\title{
THE DENNING LAW JOURNAL
}

group of hunters. When these group of hunters hunt on the land, no individual hunter has any incentive to increase or maintain the stock of game. This is simply because the cost of doing so will go to others as well as himself. The consequence is that there will be over intensive hunting and a reduction in the game stock which will not only affect his fellow hunters but hunters for generations to come. It is because the cost of one's use is not reflected in communal ownership that a private property regime is justified. A private scheme of ownership over game territory is much better because it:

\begin{abstract}
"will internalize many of the external costs associated with communal ownership, for now an owner, by virtue of his power to exclude others, can generally count on realizing the rewards associated with husbanding the game and increasing the fertility of his land. The concentration of benefits and costs on owners creates incentives to utilize resources more efficiently."
\end{abstract}

\section{CONCLUSIONS}

It is often thought that theorising private property is a task for political and economic philosophers rather than for property lawyers. The assumption appears to be that, how private property regimes come about and the possible justifications thereof, are questions of political and economic theory. As a result of this, an equally important assumption appears to be that political and economic theory can be divorced from any legal discourse on the system of property rules. The role of the property lawyers is to consult legal materials and advise his client on property transactions. Yet, as this article has shown, these assumptions need serious challenge. Understanding the theoretical underpinning of property rights is important for a property lawyer. The perspectives offered by the various justificatory theories of private property continue to be reflected in the case law, they also influence policy makers and legislators. Moreover, the theoretical analysis of private property serves to help the understand contemporary problems in property law by attempting to explain how such doctrinal problems have arisen and what factors have caused them. 